\title{
Digital as the Future of Indonesia Economy Growth
}

\author{
Pandu Adi Cakranegara ${ }^{\text {a }}$ * \\ ${ }^{1}$ Universitas Presiden, Cikarang, Bekasi, West Java 17530, Indonesia \\ Email : pandu_adi_cakranegara@gmail.com ${ }^{1}$ \\ * Corresponding Author
}

\section{ARTICLE INFO}

\section{Article history}

Received 2020-08-29

Revised 2020-09-12

Accepted 2020-09-19

Keywords

Digital

Porter Competitiveness of

Nation

Indonesian Future

\begin{abstract}
Indonesia is a country that is currently in a developing country position. Indonesia was predicted to be one of the strongest economies in Asia, especially during the oil boom era where Indonesia has oil reserves that are driving economic growth. However, the presence of oil cannot be used for long-term investment and the consequences of the 1998 monetary crisis prevented Indonesia from reaching its potential. In the future the country's growth will be driven by technology. This research is applied research to use Porter's Competitive Advantage model for the State. The data used are secondary data from trusted institutions for which data is publicly available. The results of this study are that Indonesia has the opportunity to become a new economy power in the future as long as it can utilize the current momentum.
\end{abstract}

\section{INTRODUCTION}

State growth according to endogenous economic growth theory consists of factors of human resources, natural resources, capital resources, and technology. Technology can be a lever factor if other resources are available. Schumpeter explains that technology creates creative destruction (Spence et al, 2006). When a country experiences population growth because old technology and technology are unable to answer, entrepreneurs will emerge who find new ways to solve the problem. With this new solution a new growth driver will emerge.

In the early 1980s Indonesia intensively conducted oil drilling. Even Indonesia is incorporated in the OPEC (Organization of Petroleum Exporting Countries) oil cartel. During this period Indonesia enjoyed an oil boom (Usui, 1996). A single company that has a monopoly on oil management in Indonesia has even grown so large that it has subsidiaries that are not related to oil, such as hotels, hospitals, catering and other business units. The government uses existing funds to subsidize oil and various other forms of subsidies. But along with that corruption grew. In the end, Indonesia is not like the North European country which has the funds managed by the state, the money from the sale of oil runs out, and then the country depends on tax revenue. The peak was in the 1998 crisis when the monetary crisis occurred and Indonesia never recovered as in the 1980s.

Since the early 1990s with the internet, the world began to enter the era of information technology (Campello et al, 2013). After the internet bubble in the early 2000s and many internet companies went bankrupt, giant internet companies emerged like Facebook, Apple, Microsoft, Google, Amazon and many other companies. These companies dominate the American stock market and have the largest capitalization (Frost et al, 2019).

A new era has begun and information technology is driving a nation's growth. Samsung became a technology giant from Korea. Meanwhile Japan has Softbank which is the largest technology investment and technology company in the world. China has Government-supported technology companies such as Alibaba, Baidu and others (Mahmood et al, 2003). In this era, Indonesia also has large technology companies in Southeast Asia such as Go Jek, Tokopedia, BukaLapak, and Blibli. The question of this research is how can Indonesia utilize this momentum to compete in the era of information technology? 


\section{THE PROPOSED METHOD}

David Ricardo was the first economist to come up with an idea about competitive advantage. Previously the mindset that existed was that a country could trade between countries if it had absolute superiority (Maneschi, 2008). An example is France selling wine because grapes are best suited for growing in France. Each country should produce what is the absolute advantage of each country and then use it for trade. But David Ricardo argues that reality doesn't have to be. Even though the country is not able to produce a superior product, if the goods can be produced with a smaller trade off in the country then the resource is feasible to produce and international trade can still occur.

Porter who is also an economist uses a variety of frameworks from economics to build what he calls the Porter Five Forces. Porter shows in his mindset what factors affect a company. The more a company has the power to control these factors, the more competitive the company will be (Porter, 2008).

Porter then developed a framework that was successfully applied to commercial companies in the non-public sector. With the same idea and making adjustments for the country level, the framework of competitive advantage of nations was born. This model is also known as the Porter diamond model because of its diamond-like shape (Bakan et al, 2012).

Diagram 1 Porter's Diamond Model

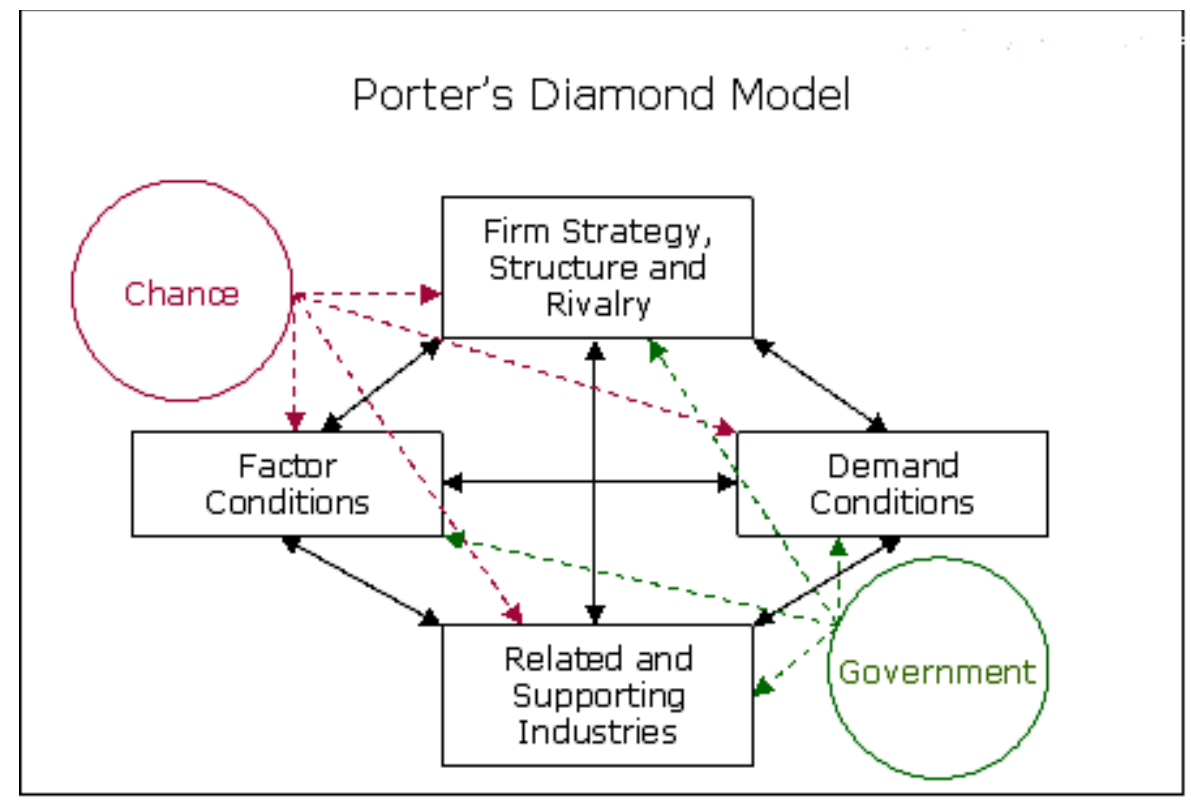

Source: Porter Competitive Advantage of Nations

In summary, Porter's Diamond Model consists of four factors:

1. Firm strategy, structure and rivalry factors talk about industry conditions and competition conditions in industries that exist in a country.

2. Demand conditions factor talks about the conditions of demand for the goods and services of the product in a country.

3. Related and supporting industries talk about the factors that support the industry to develop in a country

4. Factor and conditions talk about the natural conditions that exist in a country to support an industry. 
Of these four factors there is a by chance and some that can be managed by the state. When all these factors are present the country is in a strong position to compete. And when there are weak factors, the state can play a role in increasing and supporting these factors.

\section{METHODS}

This research is an applicative research. Applicative research is useful for bridging between theory and practice in the field. Applicative research contributes to be able to apply theories to solve real problems (Krueger, 2014). This study uses the framework of Michael Porter to analyze the competitive advantage of nations. This framework will be used in Indonesia to see Indonesia's potential in the information technology era.

The data in this study are secondary data that is data that has been collected by other parties and processed into useful information (Smith et al, 2008). The data used is publicly available data. Data sources come from trusted institutions such as McKinsey and World Bank.

Then using the data and various information available are used as input for the Porter model. After all inputs have been entered into the model, an analysis of the output of the model is analyzed to answer the question of the competitiveness of Indonesia as a country.

\section{RESULTS AND DISCUSSION}

McKinsey in diagram 2 shows the effect of the Covid 19 pandemic on the valuations of various industries. According to McKinsey's forecast the industry in the future is an industry related to technology, namely semiconductors and software, and pharmaceuticals.

Diagram 2 Industry Valuations in Covid 19 Pandemic by McKinsey

The best industries are getting better, and the worst are getting worse.

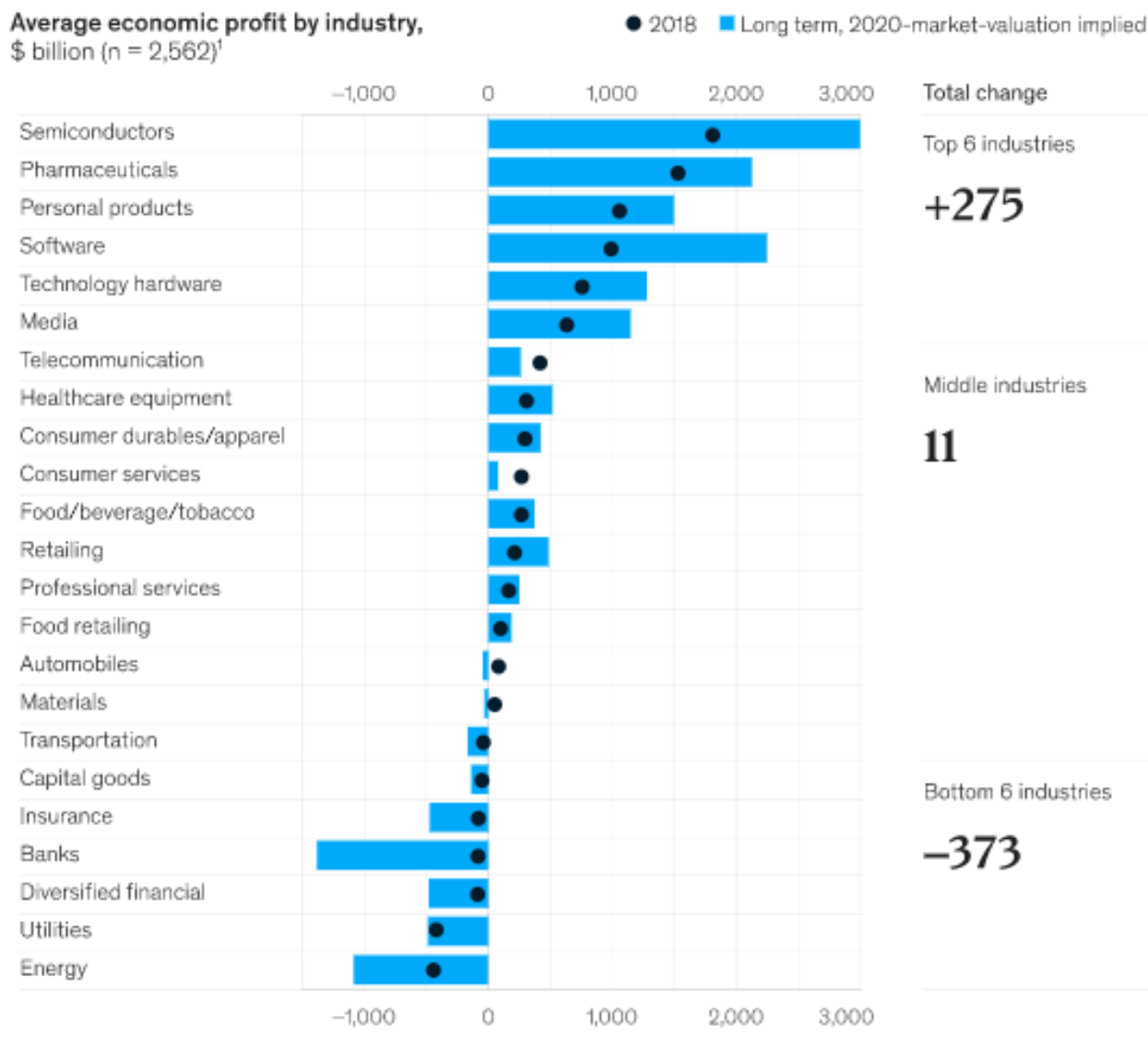

Source: McKinsey, 2020 
By using the Porter diamond framework, it can be mapped the position of Indonesia in the digital industry going forward.

\section{Demand Conditions Factor}

Indonesia is the fourth most populous country in the world. This means that potentially the demand for many consumers of technology users. With the number of young demographics and large middle class, the purchasing power of technology goods will also be high. Although the purchasing power in Indonesia is not as high as in developed countries, in Indonesia there is a leap in the use of technology with many smartphone users. In addition, the structure of Indonesian society which tends to be social makes Indonesian people become active users of social media (Guilmoto et al, 2016).

\section{Firms Strategy, Structure and Rivalry Factor}

Indonesia has a competitive environment where every start-up is free to start without any difficult regulations. So someone can immediately start up. Monopoly regulations for start-up companies are not enforced as in other fields due to the different nature of the digital world (Utting, 2005).

\section{Related and Supporting Industries Factor}

In Indonesia there are many universities which mean many graduates are educated workers, especially in terms of technology. This means two things: the number of young people who start up and the number of young people who are interested in working at start-ups (Oosterbek et al., 2010).

In terms of funding, there is a lot of venture capital ready to provide funds and invest. This financial institution also works with universities to establish incubators with universities. It is hoped that at the university level, these aspiring entrepreneurs receive intensive guidance so that the startup they have has a mature concept and is ready to compete.

\section{Conditions Factor}

Indonesia has consumers who are able to accept new things. This makes technology companies acceptable in Indonesia. In addition Indonesia has natural resource factors, namely mining materials such as nickel and various other mining materials which are commodities to produce hardware technology (Dutu, 2015).

\section{Government Factor}

The Government of Indonesia supports the stand-up start-up and technological progress (Pickernel et al, 2013). In particular, the government established the Creative Economy Agency to support the progress of the creative economy. The government also facilitates various start-up businesses by pushing regulations to help start-ups. One example is the government permitting twowheeled vehicles to be used as a means of transporting and regulating goods. This is different from some countries in Southeast Asia where two-wheeled vehicles are private and cannot be used as public transport vehicles for passengers.

\section{Putting All Things Together}

From the analysis of the factors in Porter's Diamond framework, Indonesia has the potential to become one of the developed countries due to digital technology. Indonesia has all the right recipes, namely human resources, natural resources which are referred to as coincidental factors. What is meant by coincidental factors is the superiority of the state because of God's grace without humans needing to work. In addition, Indonesia is also in a young demographic that is profitable to switch to the digital industry. Another factor is the condition of Asia which is currently experiencing economic growth driven by China so that a lot of capital is flowing into Asia (Chow, 2017). The Indonesian technology platform is a user. 


\section{CONCLUSION}

Indonesia has the opportunity to become one of the developed countries in the digital economy (Minniti, 2008). Porter Framework helps identify supporting factors and factors that still need to be improved. The government has an important role in bringing Indonesia into the digital era. If this momentum is not utilized then it can happen like in the 1980s when Indonesia had the opportunity to become a developed country with oil money but failed to use it.

\section{REFERENCES}

Bakan, İ., \& Doğan, İ. F. (2012). Competitiveness of the industries based on the Porter's diamond model: An empirical study. International Journal of Research and Reviews in Applied Sciences, 11(3), 441-455.

Campello, M., \& Graham, J. R. (2013). Do stock prices influence corporate decisions? Evidence from the technology bubble. Journal of Financial Economics, 107(1), 89-110.

Chow, G. C. (2017). Capital formation and economic growth in China (pp. 1186-1221). Brill.

Dutu, R. (2015). Making the most of natural resources in Indonesia.

Frost, J., Gambacorta, L., Huang, Y., Shin, H. S., \& Zbinden, P. (2019). BigTech and the changing structure of financial intermediation. Economic Policy.

Guilmoto, C. Z., \& Jones, G. W. (Eds.). (2016). Contemporary demographic transformations in China, India and Indonesia. Springer International Publishing.

Krueger, R. A. (2014). Focus groups: A practical guide for applied research. Sage publications.

Mahmood, I. P., \& Singh, J. (2003). Technological dynamism in Asia. Research policy, 32(6), 1031-1054.

Maneschi, A. (2008). How would David Ricardo have taught the principle of comparative advantage?. Southern economic journal, 1167-1176.

Minniti, M. (2008). The role of government policy on entrepreneurial activity: productive, unproductive, or destructive?. Entrepreneurship theory and Practice, 32(5), 779-790.

Oosterbeek, H., Van Praag, M., \& Ijsselstein, A. (2010). The impact of entrepreneurship education on entrepreneurship skills and motivation. European economic review, 54(3), 442-454.

Pickernell, D., Senyard, J., Jones, P., Packham, G., \& Ramsey, E. (2013). New and young firms: Entrepreneurship policy and the role of government-evidence from the Federation of Small Businesses survey. Journal of Small Business and Enterprise Development, 20(2), 358-382.

Porter, M. E. (2008). The five competitive forces that shape strategy. Harvard business review, 86(1), 25-40.

Smith, E., \& Smith Jr, J. (2008). Using secondary data in educational and social research. McGraw-Hill Education (UK).

Spencer, A. S., \& Kirchhoff, B. A. (2006). Schumpeter and new technology based firms: Towards a framework for how NTBFs cause creative destruction. International Entrepreneurship and Management Journal, 2(2), 145156.

Usui, N. (1996). Policy adjustments to the oil boom and their evaluation: the Dutch disease in Indonesia. World Development, 24(5), 887-900.

Utting, P. (2005). Rethinking business regulation: From self-regulation to social control. Geneva: United Nations Research Institute for Social Development. 